\title{
Macro Propagation of Long Internode Schizostachyum dulloa (Gamble) R. B. Majumdar through Culm Cutting
}

\author{
J. Pathak", M.B. Tandel, S.M. Patel, J.R. Chavda and D.H. Prajapati \\ Department of Silviculture and Agroforestry, College of Forestry, Navsari Agricultural \\ University, Navsari - 396 450, Gujarat, India \\ *Corresponding author
}

\begin{tabular}{|l|}
\hline K e y w o r d s \\
$\begin{array}{l}\text { S. dulloa, Macro } \\
\text { propagation, Plant } \\
\text { growth regulators, } \\
\text { Long internode, } \\
\text { Auxins }\end{array}$ \\
\hline Article Info \\
\hline $\begin{array}{l}\text { Accepted: } \\
\text { 04 February } 2018 \\
\text { Available Online: } \\
\text { 10 March } 2018\end{array}$ \\
\hline \hline
\end{tabular}

The present investigation entitled "Macro Propagation of long internode Schizostachyumdulloa(Gamble) R.B. Majumdar" waslaid out at Bamboo Nursery, College of Forestry, ASPEE College of Horticulture and Forestry, Navsari Agricultural University, Navsari during March-2015 to June-2017.Three year old bamboo culms of Schizostachyumdulloa(Gamble) R.B. Majumdarwas selected for investigation. Three noded bamboo culm cuttings were sterilized with the fungicideafter that administered with different concentration of Plant Growth Regulators (auxins). The results revealed the highest percentage of cuttings sprouted (66.67\%), percentage of cuttings rooted $(63.58 \%)$, number of leaves per plant (29.17), number of roots $(12.11)$, length of root $(21.50 \mathrm{~cm})$, days taken for initiation for first sprouting (20.73 days), length of sprouts $(70.37 \mathrm{~cm})$ and percentage of plants survived after transplanting $(62.35 \%)$ were recorded in combination of high concentration of NAA and low concentration of IBA i.e.treatment $\mathrm{T}_{5}-\mathrm{NAA}-500$ ppm + IBA-200 ppm. Hence, it can be concluded that the $\mathrm{T}_{5}-\mathrm{NAA}-500 \mathrm{ppm}+\mathrm{IBA}-$ 200 ppmcan be used for large scale production along with higher rate of survival of long internode bamboo $S$. dulloadue to its high demand in kite industry, flute making industry and other handicrafts.

\section{Introduction}

Bamboo is a multipurpose, fast growing woody species, which occupies an important place in the diverse phases of life and culture of the people belonging to Poaceae family. There are about 88 genera and 1400 species of bamboos distributed worldwide covering an area of more than 14 million hectares with $80 \%$ of species and area under bamboos confined to south and south-east Asia, largely in China, India and Myanmar (Wu and Raven,
2006). Bamboos form the backbone of the rural economy of many south-east Asian countries including India sustaining the livelihood of millions of people and are often referred to as "poor man's timber" (Yeasmin et al., 2014).

India is rich in bamboo genetic resource having 125 indigenous and 10 exotic species spread over an area of 8.96 million hectares which constitutes $12.8 \%$ of total forest area (Anonymous, 2003 and Rathore et al., 2009). 
North-eastern states are rich in bamboo bioresources and represent about $66 \%$ of growing stock of bamboo in the country (Rai and Chauhan, 1998). India is a well-known for kite festival especially in Gujarat state. The species recommended by Scientist T. C. Bhuyan are Bambusa polymorpha, Cephalostachyum pergracile (Schizostachyum pergracile) and Teinostachyum dullooa (Schizostachyum dullooa) because they have longer internodes and therefore could be used to make larger kites (Bhattacharya, 2014).

Among them above mentioned long internode bamboo species Schizostachyum dulloa (Gamble) R.B. Majumdar has been selected for its wide utility in making baskets, mats and small boxes. It can be used for kite industries, flute making industries and other handicrafts where long internodal length is required. Tribe of Garo hills used for carrying water and for making umbrellas.

\section{Materials and Methods}

The present investigation entitled "Macro Propagation of long internode Schizostachyum dulloa (Gamble) R.B. Majumdar" was laid out during March - 2015 to June - 2017, at the Bamboo nursery at College of Forestry, ASPEE College of Horticulture and Forestry, Navsari Agricultural University, Navsari, Gujarat, India which is situated at an altitude of about 12 meters above mean sea level, 20058' North latitude and 720-54' East longitude. Experimental material (Rhizome)s were brought from RFRI, Jorhat, Assam, KFRI, Kerala and Bambusetum Silva division Forest department, Rajpipla, Gujarat. Three years old plants of $S$. dulloa raised in Bambusetum of ASPEE College of Horticulture and Forestry was selected for the present investigation. In the present investigation, effect of forms of Auxins NAA, IBA, Boric acid and Coumarin and combination of both on the performance of culm cuttings of $S$. dulloawas studied. Treatment consists of $\mathrm{T}_{1}$ : Control, $\mathrm{T}_{2}$ : NAA200ppm, $\mathrm{T}_{3}$ : NAA-500 ppm, $\mathrm{T}_{4}$ : NAA200ppm+ IBA-500ppm, T5: NAA-500 ppm+ IBA-200 ppm, T 6 : IBA-200 ppm, T 7 IBA-500 ppm, $\mathrm{T}_{8}$ : Boric acid 200ppm, $\mathrm{T}_{9}$ : Coumarin 200ppm, T 10 : Coumarin 200ppm + IBA 200ppm and $\mathrm{T}_{11}$ : Coumarin 200ppm + IBA 200ppm + NAA-200ppm with 3 repetition. Nine culm cuttings of each treatment under each repetition were planted in the planting media under sand, soil and vermicompost in $2: 1: 1$ ratio.

Observations were recorded under experiment are percentage of cutting sprouted (\%), percentage of cutting rooted, number of leaves per plant, number of roots at the end of experiment, length of roots, days taken for initiation of first sprouting, length of sprout at the end of experiment and survival percentage after transplanting in polybags. The recorded observations were analyzed with CRD as prescribed by Panse and Sukhatme (1967).

\section{Results and Discussion}

\section{Growth parameters}

The recorded pooled results depicted in Table 1 pertaining to growth parameters revealed that the highest percentage of cuttings sprouted (66.67 \%), maximum length of sprout at the end of experiment $(70.37 \mathrm{~cm})$, minimum days taken for initiation first sprouting (20.73) and number of leaves per plant (29.17) were recorded in combination of high concentration of NAA and low concentration of IBA i.e. treatment $\mathrm{T}_{5}$ - NAA$500 \mathrm{ppm}+$ IBA-200 ppm while minimum or lowest values were recorded in $\mathrm{T}_{1}$ : Control for all growth parameters $(2.47 \%, 8.81 \mathrm{~cm}, 43.92$ days and 2.50, respectively). Treatment $\mathrm{T}_{5}-$ NAA-500 ppm + IBA-200 ppm was followed by $\mathrm{T}_{7}$ : IBA-500 ppm. 
Table.1 Effect of plant growth regulators on growth parameters of Schizostachyum dulloa (Gamble) R.B. Majumdar

\begin{tabular}{|c|c|c|c|c|c|}
\hline Treatments & $\mathbf{1}$ & $\mathbf{2}$ & $\mathbf{3}$ & $\mathbf{4}$ \\
\hline & $\mathbf{P C S}(\boldsymbol{\%})$ & $\mathbf{N L P}$ & DTIFS & $\mathbf{L S}(\mathbf{c m})$ \\
\hline $\mathbf{T}_{\mathbf{1}}$ & 2.47 & 2.50 & 43.92 & 8.81 \\
\hline $\mathbf{T}_{\mathbf{2}}$ & 3.29 & 4.67 & 39.17 & 12.24 \\
\hline $\mathbf{T}_{\mathbf{3}}$ & 4.53 & 5.33 & 39.22 & 16.55 \\
\hline $\mathbf{T}_{\mathbf{4}}$ & 37.96 & 17.17 & 31.94 & 38.61 \\
\hline $\mathbf{T}_{\mathbf{5}}$ & 66.67 & 29.17 & 20.73 & 70.37 \\
\hline $\mathbf{T}_{\mathbf{6}}$ & 48.46 & 22.83 & 28.94 & 59.05 \\
\hline $\mathbf{T}_{\mathbf{7}}$ & 61.11 & 27.33 & 25.35 & 60.68 \\
\hline $\mathbf{T}_{\mathbf{8}}$ & 7.10 & 13.50 & 41.09 & 22.83 \\
\hline $\mathbf{T}_{\mathbf{9}}$ & 28.03 & 14.17 & 31.50 & 33.11 \\
\hline $\mathbf{T}_{\mathbf{1 0}}$ & 21.23 & 10.83 & 34.83 & 29.33 \\
\hline $\mathbf{T}_{\mathbf{1 1}}$ & 5.56 & 10.17 & 41.39 & 26.67 \\
\hline SEM (T) & 0.99 & 0.61 & 1.17 & 1.23 \\
\hline $\mathbf{C D}(\mathbf{T})$ & 2.90 & 1.79 & 3.45 & 3.62 \\
\hline SEM (Y XT) & 1.39 & 0.86 & 1.66 & 1.74 \\
\hline $\mathbf{C D}(\mathbf{Y} \mathbf{X}$ ) & $\mathrm{NS}$ & $\mathrm{NS}$ & $\mathrm{NS}$ & $\mathrm{NS}$ \\
\hline $\mathbf{C V}$ & 9.28 & 10.41 & 8.35 & 8.77 \\
\hline
\end{tabular}

Table.2 Effect of plant growth regulators on root parameters of Schizostachyum dulloa (Gamble) R.B. Majumdar

\begin{tabular}{|c|c|c|c|}
\hline Treatments & $\mathbf{5}$ & $\mathbf{6}$ & $\mathbf{7}$ \\
\hline $\mathbf{T}_{\mathbf{1}}$ & $\mathbf{P C R}(\mathbf{\%})$ & $\mathbf{N R}$ & $\mathbf{L R}(\mathbf{c m})$ \\
\hline $\mathbf{T}_{\mathbf{2}}$ & 0.00 & 0.00 & 0.00 \\
\hline $\mathbf{T}_{\mathbf{3}}$ & 0.00 & 0.00 & 0.00 \\
\hline $\mathbf{T}_{\mathbf{4}}$ & 1.64 & 0.91 & 1.50 \\
\hline $\mathbf{T}_{\mathbf{5}}$ & 38.58 & 6.83 & 13.63 \\
\hline $\mathbf{T}_{\mathbf{6}}$ & 63.58 & 12.11 & 21.50 \\
\hline $\mathbf{T}_{\mathbf{7}}$ & 46.30 & 7.50 & 15.78 \\
\hline $\mathbf{T}_{\mathbf{8}}$ & 58.64 & 11.17 & 17.30 \\
\hline $\mathbf{T}_{\mathbf{9}}$ & 7.41 & 1.41 & 9.63 \\
\hline $\mathbf{T}_{\mathbf{1 0}}$ & 26.54 & 4.89 & 11.47 \\
\hline $\mathbf{T}_{\mathbf{1 1}}$ & 16.36 & 2.39 & 10.77 \\
\hline $\mathbf{S E M}(\mathbf{T})$ & 4.94 & 1.61 & 5.98 \\
\hline $\mathbf{C D}(\mathbf{T})$ & 1.09 & 0.16 & 0.41 \\
\hline SEM (Y XT) & 3.21 & 0.46 & 1.20 \\
\hline $\mathbf{C D}(\mathbf{Y} \mathbf{X} \mathbf{T})$ & 1.54 & 0.22 & 0.58 \\
\hline $\mathbf{C V}$ & $\mathrm{NS}$ & $\mathrm{NS}$ & 1.69 \\
\hline & 11.15 & 8.71 & 10.19 \\
\hline
\end{tabular}


Table.3 Effect of plant growth regulators on survival percentage after transplanting in bag of Schizostachyum dulloa (Gamble) R.B. Majumdar

\begin{tabular}{|c|c|}
\hline Treatments & $\mathbf{8}$ \\
\hline & PSAT $(\%)$ \\
\hline $\mathbf{T}_{\mathbf{1}}$ & 0.00 \\
\hline $\mathbf{T}_{\mathbf{2}}$ & 0.00 \\
\hline $\mathbf{T}_{\mathbf{3}}$ & 0.00 \\
\hline $\mathbf{T}_{\mathbf{4}}$ & 40.74 \\
\hline $\mathbf{T}_{\mathbf{5}}$ & 62.35 \\
\hline $\mathbf{T}_{\mathbf{6}}$ & 48.15 \\
\hline $\mathbf{T}_{\mathbf{7}}$ & 59.88 \\
\hline $\mathbf{T}_{\mathbf{8}}$ & 9.26 \\
\hline $\mathbf{T}_{\mathbf{9}}$ & 34.07 \\
\hline $\mathbf{T}_{\mathbf{1 0}}$ & 25.93 \\
\hline $\mathbf{T}_{\mathbf{1 1}}$ & 5.55 \\
\hline $\mathbf{S E M}(\mathbf{T})$ & 0.95 \\
\hline $\mathbf{C D}(\mathbf{T})$ & 2.78 \\
\hline SEM (Y XT) & 1.34 \\
\hline $\mathbf{C D}(\mathbf{Y} \mathbf{X})$ & $\mathrm{NS}$ \\
\hline $\mathbf{C V}$ & 8.92 \\
\hline
\end{tabular}

1. PCS (\%): Percentage of cuttings sprouted

2. NLP: Number of leaves per plant

3. DTIFS: Days taken for initiation first sprouting

4. LS (cm): Length of sprout at the end of experiment

5. PSAT (\%): Percentage of plants survived after transplanting

6. PCR $(\%)$ : Percentage of cuttings rooted

7. NR: Number of roots at the end of experiment

8. LR $(\mathrm{cm})$ : Length of root $(\mathrm{cm})$

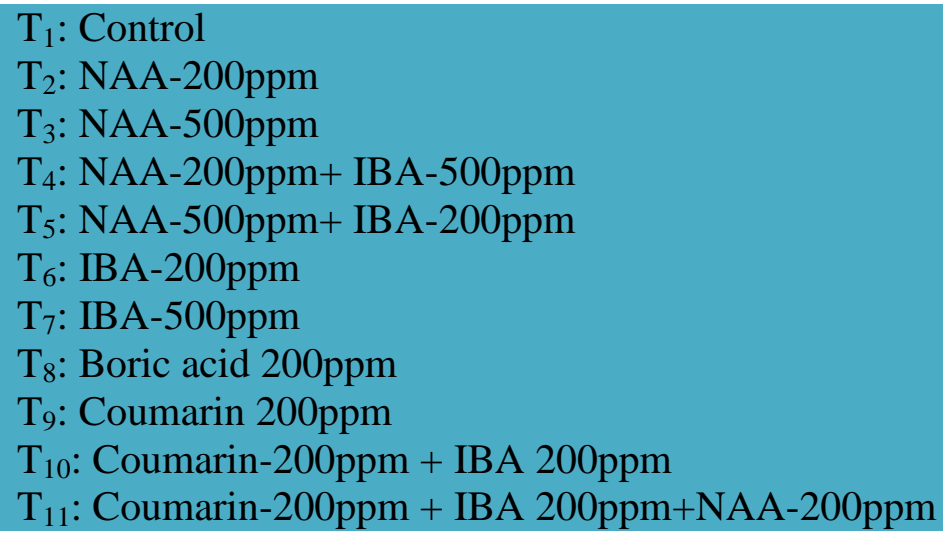


The data depicted in Table 1 clearly revealed that combination of high concentration of $\mathrm{NAA}+$ low concentration of IBA and IBA alone were found to be more effective than NAA, Boric acid, Coumarin and Coumarin combination in different concentration in $S$. dulloa. The treatment $\mathrm{T}_{5}$ (NAA-500 ppm + IBA-200 ppm) recorded significantly maximum percentage of sprouting, sprout length, number of leaves per plant and at the end of experiment as well as earlier sprouting in $S$. dulloa. The next best treatment in order to response in all growth parameters is $\mathrm{T}_{7}$ (IBA 500 ppm).Variable response among various bamboo species generally resulted due to the differences in morphological features and endogenous levels of stored photosynthates and axillary substances. These results are in close proximity with the earlier findings of Saharia and Sen (1990). The exogenous application of various growth regulators, mostly auxins, has been reported to positively influence on induction and growth in culm cuttings of bamboos (Agnihotri and Ansari, 2000 and Singh et al., 2002). Exogenous application of auxins becomes effective if their endogenous level is low for example due to inactive growth phase or less accumulation in distal plant parts. Similar trends of results were earlier reported by Nath et al., (1986) in Bambusa pallida and Teinostachyum dullooa.

\section{Root parameters}

It is evident from the data pertaining to root parameters presented in Table 2 that highest percentage of cuttings rooted $(63.58 \%)$, number of roots at the end of experiment (12.11) and length of root $(21.50 \mathrm{~cm})$ were recorded in the treatment combination of $\mathrm{T}_{5}$ : NAA-500 ppm + IBA-200 ppm. However, no rooting was observed in $\mathrm{T}_{1}$ : Control and $\mathrm{T}_{2}$ : NAA $200 \mathrm{ppm}$. The second best treatment found for all root parameters was $\mathrm{T}_{7}$ : IBA 500 ppm. Variable response in percentage of cuttings rooted might be due to different genetic makeup of $S$. dulloa. Moreover, these variations are also due to varied endogenous natural auxins in different species of bamboo. Similar result was earlier reported by Saharia and Sen (1990). The variation in rooting ability observed due to tried auxins and their combinations may be attributed to species ability of signal reorganization and its amplification which depends on genetic makeup of the species. These results are in close proximity with the earlier findings of Seethalakshmi et al., (1983), Nain et al., (2007) in B. tulda and B. vulgaris, Rana et al., (1987) in Dalbergia sissoo and Nautiyal (1991) in Tectona grandis.

\section{Survival percentage after transplanting in bag}

As per the obtained pooled result of two years depicted in Table 3 it is evident that maximum percentage of plants survived after transplanting in poly bags $(62.35 \%)$ was recorded in treatment combination of $\mathrm{T}_{5 \text { : }}$ NAA-500 ppm + IBA-200 ppm which was statistically at par with $\mathrm{T}_{7}$ : IBA $500 \mathrm{ppm}$ $(59.88 \%)$. while lowest survival percentage $(0.00 \%)$ was recorded in $\mathrm{T}_{1}$ : Control, $\mathrm{T}_{2}$ : NAA-200 ppm and $\mathrm{T}_{3}$ : NAA-500 ppm.

From the above depicted experimental results and discussion in the above section it is concluded that the maximum values were recorded with respect to growth and root parameters viz. percentage of cuttings sprouted, maximum length of sprout at the end of experiment, minimum days taken for initiation first sprouting, number of leaves per plant, percentage of cuttings rooted, number of roots at the end of experiment, length of root $(\mathrm{cm})$ and percentage of survival after transplanting in $\mathrm{T}_{5}$ : NAA-500 ppm + IBA-200 ppm which was followed by $\mathrm{T}_{7}$ : IBA 500 ppm. While, percentage of survival after transplanting was statistical at par with the 
same treatment. Therefore, it is concluded that the treatment combination of high concentration of NAA and low concentration of IBA i.e., $\mathrm{T}_{5}$ : NAA-500 ppm + IBA-200 ppm can be used for mass propagation of long internode bamboo $S$. dulloa through culm cutting method to mitigate shortage of long internode bamboo in kite industry, flute making industry and other handicrafts.

\section{References}

Agnihotri, K. and Ansari, S. A. (2000). Adventitious rhizogenesis in relation to seasonal variation, size of culm branch cutting and IAA treatment in bamboos. Indian Forester, 126 (8): 971-984.

Anonymous. (2003). National Mission on Bamboo technology and trade development. Published by planning commission, Govt. of India.Pp.176.

Bhattacharyya, S. (2014). www. telegraphindia.com/114011/jsp/north east/story.

Nain, N. P. S., Meena, S. L., Kunjam, K. K., Tripathi, S. P. and Singh S. (2007). Clonal propagation of some bamboo species through adventitious rhizogenesis in culm cuttings. Indian Forester, 133 (2): 206-210.

Nath, M., Phukan, U., Barua, G., Devi, M., Barua, B. and Deka, P. C. (1986). Propagation of certain bamboo species from chemically treated culm cutting. Indian J. Forestry, 9 (2): 151-156.

Nautiyal, S., Singh, U. and Gurumurti, K. (1991). Rooting response of branch cuttings of Teak (Tectona grandis) as influnced by season and growth hormones. Indian Forester, 117 (4): 249 255.

Panse, V. G. and Sukhatme, P. V. (1985).Statistical methods for agricultural workers. $4^{\text {th }}$ Ed., ICAR, New Delhi, pp. 131-143.

Rai S.N. and Chauhan K.V.S. (1998) Distribution and growing stock of bamboos in India. Indian Forester, 124 (2), 89-98.

Rana, U., Gairola, A. and Nautiyal, A. R. (1987). Seasonal variation in rooting of stem cuttings of Dalbergia sissoo and auxin effects on it. Indian J. Forestry, 10 (3): $220-222$.

Rathore, T. S., Kabade, U., Jagadish, M. R., Somashekar, P. V. and Viswanath, S. (2009). Micropropagation and evaluation of growth performance of the selected industrially important bamboo species in southern India. VIII World Bamboo Congress Proceedings, 6:41-55.

Saharia, U. K. and Sen, S. K. (1990).Optimum age of bamboo culms for nodal cuttings. Indian Forester, 116 (10): 780-784.

Seethalakshmi, K. K., Venkatesh, C. S. and Surendran. T. (1983). Vegetative propagation of bamboo using growth promoting substances. Indian J. Forestry, 6 (2): 98-103.

Singh, S., Ansari, S.A. and Kumar, P. (2002).Clonal propagation of Bambusa nutans through culm and branch cutting. Indian Forester, 128 (1): 35-40.

$\mathrm{Wu}, \mathrm{Z}$. Y. and Raven, P. H. (2006). Flora of China: Poaceae. Volume 22, Beijing: Science Press, St. Louis: MBG Press.

Yeasmin, L., Ali, M.N., Gantait, S. and Chakraborty, S. (2014). Bamboo: an overview on its genetic diversity and characterization. Biotech, 3: 1-11.

\section{How to cite this article:}

Pathak, J., M.B. Tandel, S.M. Patel, J.R. Chavda and Prajapati, D. 2018. Macro Propagation of Long Internode Schizostachyum dulloa (Gamble) R. B. Majumdar through Culm Cutting. Int.J.Curr.Microbiol.App.Sci. 7(03): 78-83. doi: https://doi.org/10.20546/ijcmas.2018.703.009 